\title{
Qualitative Chemistry Education: The Role of the Teacher
}

\author{
Bugaje, Bad0yya Muhammad (Mrs.) \\ Department Of Chemistry Federal College Of Education, Zaria, Nigeria.
}

\begin{abstract}
This paper discussed the role of a chemistry teacher towards improving the quality of education in Nigeria. The decline in the quality of education has been attributed to many factors. Some of these factors are unqualified teachers, examination malpractice, lack of practical skills, method of classroom instruction, to mention but a few. The role of a chemistry teacher among others is to change the method of classroom instruction from lecture method to innovative learning strategy such as cooperative learning and concept mapping, and to make use of improvised materials in the absence of standard equipments. It also examine the problems associated with the fall in quality of education. Finally it is recommended that Government should ensure that adequate funds are released to train science teachers, since teachers are the main determinant of quality in Education.
\end{abstract}

\section{Introduction}

As a developing nation, Nigeria appreciates the importance of science education in development and the teacher is vital in the education substratum. The quality of any educational program depends on the quality of those who teach it , This underscores the importance that should be attached to the production of high quality teachers (Pemida, 2005) .

While making an observation on the fall of quality of education in Nigeria, Maiwada (2003) lamented that, nowadays it is not uncommon to hear complaints by employees about incompetence of graduate employers especially in situation demanding practical work .Furthermore available reports on the quality of teachers generally indicted teachers of incompetence (Ali, 1999, Iwowi 1990, Adeyegbe 1993, 1998 in Onu, 2005).

Qualitative Science education, chemistry being central at all level of our education is a critical pivot to moving the country to greater advancement. It is however observed with dismay the continuous decline in the quality of chemistry education, which expresses it self in poor and unimpressive performance at the Senior Secondary Certificate Examination (WAEC Chief examiners report 1999 - 2002, Njoku 1999 in Njoku 2002 ). The reason for the failure has been attributed to many factors among which are, teacher quality (Onu 2005), teaching method (Efe 2005), lack of availability of human and material resources (Lawrence and Tanko 1998, and Agusiobo 2002 ) and neglect of practical work (Akale and Usman 1993 in Akale and Nwankwanta 1998 ).

The decline in the quality of education has been attributed to many factors. Some of these factors are defective planning, unqualified teachers, examination malpractice, misadministration, poor maintenance and repairs, inadequate financing, and mismanagement (Batagarawa 2005). .

\section{Role of a Chemistry Teacher Towards Improving the Quality of Science Education in Nigeria}

The National Science curriculum has three basic science subjects (Biology Chemistry Physics) of which a student is expected to choose one at the Secondary School level of the Nigeria Education ( Ihuathum 2008). Among these basic science subjects chemistry occupies a unique position. It is a pre - requisite for the study of many science courses, such as medicine, biochemistry, pharmacy, agricultural science, laboratory technology, .geology, agricultural science and so on (Ihuarulam, 2008).

The role and importance of chemistry are clearly seen and known in the scientific and technological development. Therefore a chemistry teacher should strategize some of which are discussed below, towards improving the quality of chemistry education.

\section{Method of instruction}

It has been observed that most students fear chemistry and hence wrongly perceived chemistry as difficult $\mathrm{t}$ to understand. It was equally observed that many factors such as poor teaching methods, mathematics nature of chemistry, and abstract nature of chemistry concepts and laws account for students poor performance (Ekejiorfor 1993 in Njoku 2005 ). . The following characteristics among others encourage effective teaching processes; a good knowledge of the subject matter, understanding of basic principles of child development, ability to employ different effective teaching strategies, and ability to adopt teaching to local situation (Nacino Brown et al 1985 in Danmaigoro 2005). The method of teaching could be regarded as the vehicle through which a message is delivered, the wrong perception by the students may imply that the delivery of chemistry has been through the wrong method. Consequently, it has become necessary to seek innovative learning strategies to 
enhance the quality of instruction and learning of chemistry. Some of these innovative learning strategies are discussed below;

\section{Cooperative Learning Strategy}

Adeyemo (2010) define cooperative learning as a teaching strategy in which students work together in small teams and use a number of activities to achieve academic objectives and improving their understanding of subject matter. The importance of cooperative learning strategy cannot be over emphasized in that it enhance students learning by providing a shared cognitive set of information between students and motivates students to learn the method (Mills, 1996). Furthermore Adeyemo (2010) observed that cooperative learning creates natural interactive context in which students have reasons for listening to one another, asking questions, clarifying issues and restating points of view. The teacher's role changes from giving information to facilitating students learning.

A number of research works have been carried out on the efficacy of cooperative learning in Nigeria(Okebukola 1984, Alebiosu !1998, Esan, 1999, Amosun 2002 in Adeyemo, 2010, Adeyemi 2002).It was the conclusion of all these studies that cooperative learning strategy seen most useful than other instructional strategies .

\section{Concept mapping}

Concept mapping is an instructional strategy that involves the use of diagrams in which concepts are organized into a hierarchical network depicting the relationship among concepts (Efe, 2005). Concept maps reflects conceptual organization of a displined segment. Here key or primary concepts are derived in a descending manner.

This learning strategy is useful in facilitating meaningful learning and it has been used to evaluate learning and as study skills leading to meaningful learning and high achievement in science (James, 2005).There are strong arguments in support of concept mapping as an innovative learning strategy that can be used by teachers and their students, to make science learning more meaningful by assisting students to organize incoming information and constructing mental bridges between what is already known and what is to be learned (Schmid andTelaro 1990, Novak , 1991 in Egbebedia, 1999).

\section{Information Communication Technology (ICT)}

Information and Communication Technology is defined as the technology of creating, processing, storage, retrieval, and transmission of data and information including telecommunication, satellite technologies, electrical and electronic (hard ware) and electronic computing (soft ware), the internet and global systems of mobile communication (GSM), Afolabi et al, 2005).

Different concepts, theories and principles can be demonstrated in the class by using ICT. This gives the teacher a meaningful classroom instruction and this enhance the teaching and make class presentation an exiting one. Computer instruction assist science teaching in the following ways, as outlined by Musa (2005).

- Laboratory data analysis / process.

- Simulating and modeling.

- $\quad$ Drill and practice.

- Teacher's ability (word processing record keeping).

In chemistry, industrial processes like manufacture of sulphuric acid, could be taught using simulation (Ojo, 2005). Simulation is one of the Computer Assisted Instruction (CAI) methods that can be employed in teaching some topics that involve either industrial processes or processes that;

* involve evolution of large amount of energy

* are too fast, for example collisions.

* involve too small subatomic charges.

Similarly, for students like chemical engineering students to obtain a clear understanding of physical processes going on inside the complex industrial scale equipment they study in the laboratory, computer simulation can be used to show the solutions to the differential equation that govern the fluid flow, heat transfer and chemical reactions among others within the equipment. This will solidify the link between experiment and theory and provide improved learning (Abubakar and Rilwanu ,2010) .

There are many advantages of using ICT at an instructional strategy. It has been observed that students learning rate is faster with CAI than with conventional instruction and this enhanced learning rate is accompanied with high retention (Ojo 2005). 


\section{Improvisation}

The need for improvisation arises due to the inability to provide the materials needed for students population. The need also arises due to high cost for standard equipments, shortage in the availability and production of known standard equipment and also the need to promote scientific thinking and the inability to internalize chemistry process and skills (Balogun, 1982 in Bugaje 2008).

It is the duty of a chemistry teacher to identify and enumerate the resources available in his environment, organized and managed them for effective teaching. This may improve the quality of education as improvisation developed functional knowledge and manipulative skills. According to Ibrahim et al (2010) improvisation serve the following functions:

- It encourages individuality, self reliance and self independence .

- Improvisation of teaching aids allow teachers and students to achieve educational goals and lesson objectives particularly the three domains of taxonomy of learning namely effective, cognitive, and psychomotor aspect of life.

- Practical work in improvisation allow students to have consistency in learning.

- Improvisation equally allows a very high degree of involvement of students in scientific and technological practice which makes teaching and learning meaningful and void of rote learning.

- Improvisation facilitates originality since most work on improvisation are for individuals.

Problems Associated with the fall in Quality of Science education in Nigeria

Some of the problems associated with the fall in quality of science education in Nigeria include;

- lack of qualified and dedicated teachers.

- Lack of practical skills

- Examination malpractice.

\section{Lack of qualified and dedicated teachers.}

Teachers are the main determinates of quality in education. If they are apathetic, uncommitted, uninspired, lazy, unmotivated, anti - social , the whole nation is doomed. If they are ignorant in their displined and impart wrong knowledge, they become not only useless but dangerous (Musa 2005) .

Qualified and sufficient number of dedicated teachers are needed to teach the content or direct the curriculum. Unfortunately many of Nigerian schools lack adequate qualified and dedicated teachers to teach science courses in schools .(Akale 1992, Lawrence and Tanko 1998, Kassim). A study on the constraints to effective implementation of the Senior Secondary School physics curriculum revealed that lack of physics teacher as a major problem which hinders implementation of the Senior Secondary School physics curriculum (Agusiobo, 2002).

\section{Lack of practical skills}

Chemistry practical skills are science process skills which are the foundation for both enquiry and development of intellectuals and individual skills needed for learning science concepts(Harden 1983 in Efe 2008).

Science teaching is more effective if students are involved in laboratory work in which the atmosphere is condusive (Akale and Nwankwonta 1998). Akalonu (1995) in Efe (2008) found that students fails to acquire the necessary practical skills for success in the SSCE chemistry practical examination. WAEC chief examiner's report, 1999 - 2002 indicated that students have many weaknesses in the practical aspect of the chemistry examination.

Generally speaking because of large number of students admitted especially at universities, opportunities for practicals are fast diminishing. Students make do with observation rather than doing. In the sciences and technology mere observations do not facilitate learning; practical are essential (Maiwada, 2003).

\section{Examination malpractice}

Examination malpractice can be viewed simply as failure on the part of the examinee examiner and others connected with the conduct of examination to comply fully with the rules and regulation guiding the conduct of examination. It could occur before during and after the conduct of examination (Ganiyu, 2006).

Perpetrators of exam malpractices are examinees, examiners, educational institutions administrators and staff; security personnel, staff of public examination body, parents/guardians, supervisors/invigilators, club/community and employed youths; poor management of examination, moral laxity, over emphasis on certificates, corruption, exorbitant examination fees, inadequate study habit by students, fear of failure, past record of failure, inadequate financing of education, excessive lust for success and rewards, overcrowded examination hall, teacher and school status, inadequacies in public examination, location of examination centers, poor condition of service for teachers, personal factors, inadequate government among others are factors 
responsible for examination malpractice as identified by several educators ( Akanbi 1996, Akande 2000: Egbegbedia 2000 Ijaija 2000, Olanipekun 2003 world bank group 2001 , in Ganiyu 2006 )

Yakubu (2010) observed that the fallen standard of education in Nigeria is largely attributed to the rising cases of examination malpractice. This has generated critics of our educational system that the certificate awarded are no more genuine.

III. Recommendations

1. Chemistry teachers should change their method of instruction from lecture method to innovative teaching strategies such as Computer Assisted Instruction (CAI) cooperative learning and so on which facilitates learning.

2. Government should endeavor to provide laboratory space and facilities to enhance practical work and development of science process skills.

3. Government should ensure that adequate funds are released to train science teachers.

4. Student should be taught to develop their talent and rely on their own abilities in writing examinations and there is need to give more attention to sanction to effectively deal with malpractice cases.

5. Chemistry teachers should closely monitor their students during practical session so as to assist them in their areas of difficulties.

\section{Conclusion}

From the discussion so far, chemistry teachers should encourage student to develop interest in the student by changing their methods of teaching from traditional lecture method to innovative learning strategies to enhance the quality of instruction and learning of chemistry. Also there is no need for science departments of higher institutions to emphasize the practice of equipment development from local resources. This may enhance the quality of education in Nigeria.

\section{Reference}

[1]. Abubakar I. and Rilwanu Y. G (2010). Computer simulation as key to to enhanced learning. Conceptual over view. International Journal of computer science. 2 (1) $51-56$.

[2]. Adekunle Y.A (1997). Innovations in science teaching and mathematics. STAN 40 ${ }^{\text {th }}$ Annual conference proceedings.52-54.

[3]. Adeyemi,B.A (2010). Effects of cooperative learning and problem-solving strategies on junior secondary school student' achievement in social studies Electronic Journal of Research in Educational psychology. 16 (6) 691-708.

[4]. Adeyemo,S.A (2010). The influence of cooperative learning and problem solving strategies in Senior Secondary School achievement. International Journal of Education Research and Technology 1(1)112-120.

[5]. Afolabi,O, Adedapo, Y.A and Adeyanju O.1.(2005). Why college teachers do not use ICT facilities in teaching. Joural of e-learning (JOEL)1(1), 29.

[6]. Agbenyeku, E.U. (2001) Improving the quality of science education in Nigerian schools in the new millennium. Kasugu Journal of Education 1(1), 42-48.

[7]. Agusiobo,N.N.(2002). Constraints of effective implementation of senior secondary school physics curriculum. Journal of Technical Education Research and Development (JOTERD), 11, 43-52.

[8]. Akale M. A. G (1992). Integrated Science Programme constraints and prospects in Nigerian schools The Nigerian Teacher Today 1 (2), $96-100$.

[9]. Akale M.A.G and Nwankwonta, N.A (1998). The relationship between psycho-social environment and cognitive achievement of senior secondary students in science. The Nigerian Teacher Today 6(1) 98-102.

[10]. Batagarawa, A.M (2005). Qualitative education. What role for an accountant A paper presented at the national conference held at federal college of education, katsina.

[11]. Bugaje, B. M. (2008). Improvisation of instructional materials in the teaching and learning of chemistry, A paper presented at the $10^{\text {th }}$ Annual conference of National Association for the Advancement of Knowledge at Federal College of Education, Katsina

[12]. Danmaigoro, A. (2005). Language need for teaching science in Nigeria. Nigerian JjournaL of Science and Educational Research (NIJORSER). 1 (2) $36-39$.

[13]. Efe O.M (2005). Comparative analysis of the effect of concept mapping and talk chalk instructional technique on the performance of student in some selected topics in SSCE chemistry. Nigerian Journal of Science and Educational Research (NIJOSER) 1(1), 5257.

[14]. Efe O. M (2008). The effect of practical skills on students achievement in practical chemistry amongst some selected secondary schools in Zaria metropolis.

[15]. Egbebedia A. K (1999). Concept maps as innovative instructional strategy for facilitating meaningful learning in science . Nigerian Journal of Research in Education 2 (1) $113-118$.

[16]. Ganiyu, B. (2006). Analysis of examination malpractice perpetrated by pre-service and in- service teachers. A case study of Kwara state college of education, Ilorin . Nigerian Journal of Professional Teachers.1 (1) 21 - 29.

[17]. Ibrahim Y. S, Paulina R.D, Abubakar S. B and Abdulkadir B. (2010). The role of secondary school mathematics teachers in improvisation of instructional materials implication to universal basic education. African journal of Educational Research and Administration 3(3) $12-16$.

[18]. Ihuarulam.A.I (2008) Chemistry teachers understanding and implementation of the senior secondary chemistry curriculum. Nigeriann journal of Science and Educztional Research 4(1) $151-158$

[19]. James T (2005). The use of concept mapping and vee diagrams to facilitate meaningful learning in biology.Zaria Educator 1(1), $113-120$.

[20]. Kassim A. G (2005). Strategies for improving the teaching of science in Nigeria. A paper presented at the National Conference of science Federal College of Education, Zaria 
[21]. Lawrence, N.M and Tanko, S.(1998). The state of resources for communicating Science,Technology and Mathematics (STM) in secondary schools in Niger state. Science Teachers Association of Nigeria $39^{\text {th }}$ annual conference proceedings, 65 .

[22]. Maiwada, A. (2003). Quality control and standards in education: formidable challenges Isah kaita multidisplinary Journal Dutsinma. 1(1) $76-78$.

[23]. Mills, B. J. (1996). Cooperative learning University of Tenessee, Chicago. Musa, H. (2005). Obstacles to qualitative science education for national advancement in colleges of education and strategies for improvement. A paper presented at the $4^{\text {th }}$ national conference of federal college of education, katsina.

[24]. Njoku, Z. C (2004) Comparison of students achievement in three classes of questions in Senior Secondary School Certificate examination (SSCE) practical chemistry. The Nigerian Teacher Today. 12 (1) $44-50$.

[25]. Ojo, M.O (2005). Information and Communication Technology (ICT) and teacher preparation for basic Education. Journal of Teacher Education 8 (1) 39-41.

[26]. Onu, A. D (2005) Students under achievement in science: a closer look at the teachers competence. Nigeria journal of Science and Educational Research (NIJORSER) 1(2), $15-18$.

[27]. Pemida, R. O (2005). Achieving the objectives of teacher education in contemporaryNigeria; status and prospects. Nigerian Journal Of Science and Educational Research (NIJORSER) 1 (2), $1-6$.

[28]. WAEC chief examiners report (2003).Waec report http//wwwwaecnigeria.org/ex Yakubu,S.(2010).Minimizing malpractice in public examinations. The role of teacher education system. Journal of Student in Science and Mathematics Education 1(10) 74-82. 